\title{
Australian history - lifting haze or descending fog?
}

\author{
John Maynard
}

\begin{abstract}
Despite the deep horrors of the Aboriginal experience during the past 216 years, we continue to draw strength and inspiration from the tenacity and courage that our people displayed to survive. Across recent decades we have witnessed the fervour, patriotism and nationalistic flag-waving and bell ringing that coincided with the 1988 Bicentennial, with Reconciliation, the Olympic Games and the Federation celebrations. Any appraisal of the 100 years since Federation involves an examination of the construction of Australian history. History, it is said, is not just about what happened or when it happened, but more importantly why it happened and how it happened. In recognition of that fact, knowledge of history and its importance was for at least three quarters of the 20th century a forbidden zone for Aboriginal Australians. We were not only denied the how and the why but also the what and the when. We were written out of the historical page and efficiently erased from the social landscape.
\end{abstract}

Regardless of this negative, since the 1970s Australian historians both black and white have attempted to drag this country to a historical moral reality and accountability. From an Aboriginal viewpoint this is not something new, but more of a tradition which we need to regain. My grandfather Frederick Maynard, a pioneer Aboriginal activist, was up on a soapbox at the Domain in Sydney in the mid 1920s speaking out on the rights of Aboriginal people. He took that message to the streets of Newcastle, Kempsey, Lismore, Grafton and many other centres throughout NSW. A decade later he was followed by the likes of Bill Ferguson, Jack Patten, Pearl Gibbs and William Cooper. They took the Aboriginal protest back to the streets with the 1938 Day of Mourning protest. In 1965, inspired by the civil rights movement in the United States led by Dr Martin Luther King, Charlie Perkins instigated the 'Freedom Rides' throughout NSW.

Historically, the Aboriginal political voice was silenced and in the contemporary setting it continues to be. This point is exemplified in the largely white 'History Wars' debate, where the protagonists from within and without the academy lock horns in a media designated arena, which fans the results into flames of its own purpose. The biased coverage by the media reveals either a finely orchestrated campaign aimed directly at undermining revisionist history or has played into the hands of skilled media operators like Keith Windschuttle, Paddy McGuinness, Christopher Pearson and Piers Ackerman. 
In a highly perceptive and modern analysis of the Australian historical landscape Elizabeth McKenzie Hatton, a committed campaigner for the Aboriginal fight for justice in the 1920s, was scathing in her appraisal of the invaders. It is somewhat depressing that some of our contemporary analysts do not possess the same compassion for the horror of the Australian Aboriginal historical experience now. Many today still fail to consider the ramifications of years of persecution and neglect of Aboriginal people and issues by governments. McKenzie Hatton could well be seen to be answering the arguments of our present right wing intelligentsia and our current Prime Minister, who erroneously conclude that the actions of the past hold no relevance to present day Australians. 'The position of the remnant of the original owners of this land and at present resident in New South Wales is a blot on State and Church alike,' she wrote.

The fact that certain [A]borigines are camped under petrol tins and without certain knowledge of where their next meal is to come from is a reflection on our boastful civilization.

We may claim that we are not responsible for the actions of the original British invaders who violated their homes, shot, poisoned, burned and mutilated the natives; but we cannot claim immunity from the conditions existing at the present time, and what should not be tolerated for one moment longer than it will take to rectify matters. ${ }^{1}$

The clarity and wisdom of Hatton's words stand in stark contrast with the Windschuttle thesis that 'there was no genocide ... there was no frontier warfare' ${ }^{2}$

Archival observations are important in defending the character of some of our famous humanitarians like Threlkeld, Gribble and GA Robinson from recent illfounded assaults. Basing his argument around the assassination of the character and motivation of many of these humanitarians, Keith Windschuttle has denounced them as radical weavers of historical fiction and fantasy. He asserts that these individuals were far from genuine, compassionate witnesses, 'simple humanitarians shocked by violence they came across, most were players in a bigger game to define and implement colonial policy on Aborigines' ${ }^{3}$ In his scramble to denigrate revisionist history as an invention of politically motivated fabricators, Windschuttle has revealed the lack of time he has spent in Australian archives. He has failed to observe or recognise that right across Australia from the earliest point of settlement until the 1930s many individuals who did display a conscience wrote out against what was happening in this country.

I do not have the time or space here to recognise all of the letters or articles penned, writing out against atrocities committed against the Aboriginal population that I have uncovered. However, it is worth quoting some of these observations. An article published in the Newcastle Chronicle in 1869 stated:

We have not only taken possession of the lands of the [A]boriginal tribes of this colony, and driven them from their territories, but we have also kept up unrelenting hostility towards them, as if they were not worthy of being classed with

1. Daylight 30 October 1926

2. The Australian 1 September 2003; Windschuttle 2002b: 398-399. See also Windschuttle 2000a, 2002b.

3. Windschuttle 2000d: 6 . 
human beings, but simply regarded as inferior to some of the lower animals of creation. ${ }^{4}$

Another writer in the Sydney Morning Herald in 1904 had no doubts about what was and had gone on, pointing to the hopelessness of the Aboriginal situation:

Governments ... winked at offences with the exception of a few cases too flagrant to condone. Laws which are really no laws, honoured more in the breach than the observance are ones that Australians have become accustomed to as far as the [A]borigines are concerned ... the 'white man's burden' is necessary accompaniment to conquest and occupation, the framers of the Federal Constitution were guilty of sinful neglect towards the [A]borigines when they left the question as it always has been - each state to have the right to wallop its niggers. ${ }^{5}$

With a sarcastic and biting sting another commentator summed up the situation:

It has been said that we acquired this country not by an act of war, but by peaceful occupation. Yes, without so much as 'by your leave' we introduced ourselves as supermen and overlords; we took possession of the [A]borigines, destroyed their game and drove them from their scant water supplies. As a people they have suffered much injustice at our hands, and they have been powerless to prevent the insults and injuries that we have done to them, for our 'peaceful occupation' has meant many terrible and treacherous deeds and it now seems will finalise in the extinction of a race of the most single hearted and peaceful people on the earth today ... We who have steeped our souls in every known sin, as judged by our laws that we have made. ${ }^{6}$

These were not isolated commentaries or the work of deranged politically motivated individuals, but rather the sentiments of many observers over decades. They were not well known historical figures like Threlkeld, Gribble or Robinson who are unjustly accused by Windschuttle of pushing their own agendas ${ }^{7}-$ in contrast they were ordinary, everyday Australian citizens.

Despite the overwhelming evidence to the contrary Windschuttle's analysis concludes that:

Ever since they were formed in 1788, the British colonies in Australia were civilised societies, governed by both morality and laws that forbade the killing of the innocent. The notion that the frontier was a place where white men could kill blacks with impunity ignores the powerful cultural and legal prohibitions on such actions. For a start, most colonists were Christians to whom such actions were abhorrent. But even those whose consciences would not have been troubled knew it was against the law to murder human beings, Aborigines included, and the penalty was death. ${ }^{8}$

Windschuttle is quick to denounce missionaries like Threlkeld and Gribble as biased and lacking in trust yet his own argument hinges on the presumption of binding Christian values.

\footnotetext{
The Newcastle Chronicle 13 November 1869.

The Sydney Morning Herald 15 November 1904.

Daylight 25 May 1922.

Windschuttle 2000d: 6 .

Windschuttle 2000c: 23
} 
Another way in which Windschuttle's arguments have twisted the facts is in his statements regarding Aboriginal activism. He asserts that Aboriginal political activism and the push for self determination began in the 1960s and was instigated and led by 'white left-wing agitators'. Windschuttle concludes, in reference to Aboriginal Australia and the Torres Strait that:

Neither indigenous culture ever developed, on its own, the notion of either the state or the nation, let alone the ideas of autonomy, sovereignty or self-determination. These concepts derive from the European political tradition. They were first applied to indigenous politics by white radicals in the 1960s and were taken up by the then new Aboriginal political elite, most of whom learnt them not at the feet of tribal elders but at university.

But, contrary to this, the Australian Aboriginal Progressive Association (AAPA) had first instigated the call for 'self-determination' as applied to Aboriginal communities and people as far back as $1925 .{ }^{10}$ This all-Aboriginal organisation gained front-page media coverage in the Sydney newspapers of the time, which announced the formation of the Association under the headline 'On Aborigines' Aspirations - First Australians to Help Themselves - Self Determination'. ${ }^{11}$ Another article stated 'Aborigines in Congress - Self Determination Is Their Aim - To Help A People’. ${ }^{12}$ The message was clear and blunt: the new Aboriginal political movement was 'fighting for the preservation of rights for [A]borigines for self determination' ${ }^{13}$ This evidence quite clearly reveals that the push for Aboriginal self-determination including social, economic and political justice was not instigated and led by white left-wing radicals during the 1960s, but was an Aboriginal initiative and preceded this period by at least four decades.

At the end of the First World War many oppressed groups including blacks and Indigenous peoples around the world gained in confidence and found a political voice. The war 'altered the course of world history in ways that strongly affected black protestors in the United States and Africa' ${ }^{14}$ Many of these groups were fuelled with a surge of national and cultural pride and their political agenda was driven under the banner of "self-determination"'.15 This upsurge in international protest and demand was reflected in Australia with the rise of the Australian Aboriginal Progressive Association who gained inspiration from and would mirror many of the demands of these international black groups. ${ }^{16}$ Marcus Garvey and his Universal Negro Improvement Association was the biggest single outside influence on the platform and directive of the Australian Aboriginal Progressive Association. ${ }^{17}$ Garvey's movement is today recognised as the biggest black movement ever mobilised in the United States and its influence was far reaching. ${ }^{18}$ Garvey and his platform 'struck a response chord in the

\footnotetext{
Windschuttle 2000a:14.

The Daily Guardian 7 May 1925, 24 April 1925.

The Daily Guardian 24 April 1925.

The Daily Guardian 7 May 1925.

The Daily Guardian 7 May 1925.

Fredrickson 1995: 137.

Fredrickson 1995: 137.

Maynard 2003: 91-105.

Maynard 2003: 91-105.

Garvey 1970: 201.
} 
hearts and minds of black people from an astonishing variety of social and cultural backgrounds throughout the world' ${ }^{19}$ Sadly by the mid 1930s and in the space of only one decade 'Garveyism had disappeared as an effective organised force', 20 and the AAPA in Australia followed the Garvey movement into near total erasure from memory. In Australia, as in the United States, ${ }^{21}$ the authorities were very much a part of the erasing process. Despite holding four conferences and mobilising widespread support the Australian Aboriginal Progressive Association were simply 'hounded' out of existence by the authorities. ${ }^{22}$

Highlighting the present and continued fight of Aboriginal people to control and govern their own affairs and directives, Fred Maynard in a petition to New South Wales Labor premier Jack Lang in 1927 called for the New South Wales Aborigines Protection Board to be scrapped completely and replaced by a 'board of management comprised of capable educated [A]boriginals under a chairman to be appointed by the government'. ${ }^{23}$ Their stance was firmly cemented in the fight for Aboriginal rights to their land and through that economic viability. Maynard demanded of the government: 'Restore to us that share of our country of which we should never have been deprived'. ${ }^{24}$ He later declared the 'Australian people are the original owners of the land and have a prior right over all other people in this respect' ${ }^{25}$ Maynard and the AAPA challenged and embarrassed the New South Wales Aborigines Protection Board on several occasions. In response, the Board informed New South Wales Premier TR Bavin that Fred Maynard's 'voluble manner and illogical views are more likely to disturb the Australian [A]borigines than achieve for them improvement of conditions' ${ }^{26}$

Recently Pat Dodson declared:

We as Aboriginal people have got to stop looking at governments to keep giving us dough because that's how they co-opt us, that's how they divide us and that's how they corrupt us ... We have got to stop being co-opted into the system because the more we do that the more we participate in our own demise. ${ }^{27}$

It is telling that several decades before, the Aboriginal political leaders of the 1920s foresaw and were confronted with the very same insidious forces pitted against them. The AAPA platform was grounded in the collective good of Aboriginal people not the betterment of individuals. The AAPA were well aware of the dangers of enforced welfare dependency and warned that ration handouts and being treated as children by the government held dire consequences:

the AAPA was out to teach the people self respect, and that could only be brought about when they took on the responsibility of their own support and development. $^{28}$

9. Fredrickson 1995: 152.

20. Sommer 1998: 5.

21. Sommer 1998: 5 .

22. Horner 1994: 27, quoting a conversation between Bill Ferguson and Charlie Leon.

23. AAPA petition to Premier, 10/6/1927, Premiers Department Correspondence Files, A27/915; The Newcastle Morning Herald 2 July 1927; The Northern Star 6 July 1927.

24. AAPA petition to Premier, 10/6/1927, Premiers Department Correspondence Files, A27/915.

25. F Maynard 1927, Premiers Department Correspondence Files, A27/915.

26. Premiers Department Correspondence Files, A27/915.

27. The Weekend Australian 6-7 April 2002. 
In the contemporary scene, Aboriginal commentator Bill Jonas in his capacity as the Aboriginal and Torres Strait Islander Social Justice Commissioner stressed:

Citizenship rights alone are not enough. As a tool of social change they are inadequate and, indeed, entrench the inequality that already exists ... We need to go further with rights. We need to adopt a rights approach that does have the capacity to transform social, economic and political relations in Australia. We need to adopt social policies aimed at achieving equality, rather than assuming it; and we need to give full recognition to indigenous people's inherent rights, in particular native title. ${ }^{29}$

The echoes of the past reverberate in this quote. AAPA President Fred Maynard, in his inaugural address before 250 Aboriginal people assembled at a conference in Sydney in 1925, said:

We aim at the spiritual, political, industrial and social. We want to work out our own destiny. Our people have not had the courage to stand together in the past, but now we are united, and are determined to work for the preservation for all of those interests which are near and dear to us. ${ }^{30}$

Recognition of the same call for political, social and economic/industrial reform several decades apart clearly outlines how little progress has been genuinely achieved in that time. Evidence reveals that Aboriginal voices for decades have stated the obvious needs from an Aboriginal perspective but if the past several decades are any indicator that voice will fall on deaf ears. Charlie Perkins in a speech on Australia Day 1984 illuminated the Aboriginal situation of fear and a sense of entrapment: 'We cringe like dogs at the prospect of the 'White backlash'. We pray eternally that the White authority structure will not turn on us and impede what little progress we have made'. ${ }^{31}$

It is crucial that the past efforts of the AAPA and early 20th century Aboriginal political patriots are revealed and recognised. From an Indigenous perspective, revealing the missing jigsaw pieces of our history - for our communities and future generations - remains the crucial motivation. The revelation of our histories can play a central role in exposing the hypocrisy and lack of historical credibility of those opposing their telling. If this country is to attain maturity it must first of all deal with its past, and through that process provide a platform where both black and white can walk together to a shared future of hope, prosperity and equality. Sadly the whole thing has degenerated into a exercise of political and intellectual point-scoring with little thought or compassion for the Aboriginal suffering in the past, or for the scars of that horrific impact that remain deeply embedded in the Aboriginal psyche.

\section{References}

\section{Primary sources}

Australian Aboriginal Progressive Association (AAPA) petition to Premier, 10/6/1927, NSW Premiers Department Correspondence Files, A27/915.

\footnotetext{
The Macleay Argus 7 April 1925.

29. The Australian 22 May 2002.

30. The Daily Guardian 7 May 1925.

31. Read 2002: 279.
} 
Maynard, F 1927, Letter to the Premier, NSW Premiers Department Correspondence Files, A27/915.

Protection Board correspondence to the Premier, NSW Premiers Department Correspondence Files, A27/915.

The Australian

The Daily Guardian

The Daylight

The Macleay Argus

The Newcastle Chronicle

The Newcastle Morning Herald

The Northern Star

The Sydney Morning Herald

The Weekend Australian

\section{Secondary sources}

Fredrickson, G 1995, Black liberation: a comparative history of black ideologies in the United States and South Africa, Oxford University Press, New York.

Garvey, M 1970, Philosophy and opinions in great documents in black American history, Ducas G \& Van Doren C (eds), Proeger Publishers, New York.

Horner, J 1974, Vote Ferguson for Aboriginal Freedom, Australia and New Zealand Book Company, Sydney.

Maynard, J 2003, 'Vision, voice and influence: the rise of the Australian Aboriginal Progressive Association', Australian Historical Studies, 34(121): 91-105.

McGuinness, P 2000, Aborigines, massacres and stolen children (Editorial), Quadrant 371: 2-4.

Read, P 2001, Charles Perkins: a biography, Penguin Books, Ringwood, Victoria.

Sommer, S 1998, 'Marcus Garvey: the forgotten giant of black liberation' <http:/ / www.worldstewards.com/id22.htm>, accessed 5 Jan 04.

Windschuttle, K 2000a, 'The break-up of Australia', Quadrant, 369: 8-18.

$2000 \mathrm{~b}$, 'The myths of frontier massacres in Australian history, Part I: the invention of massacre stories', Quadrant 370: 8-21.

2000c, 'The myths of frontier massacres in Australian history, Part II: the fabrication of the Aboriginal death toll', Quadrant 371: 17-24.

2000d, 'The myths of frontier massacres in Australian history, Part III: massacre stories and the policy of separatism', Quadrant 372: 6-20.

2002a, 'The historian as prophet and redeemer', Quadrant 392: 9-18.

2002b, The fabrication of Aboriginal history. Vol 1: Van Diemen's Land, 1803-1847,

Macleay Press, Sydney. 